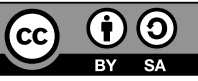

DOI: https://doi.org/10.4312/keria.20.2.245-254

\title{
Razmišljanja s popotovanja po Grčiji ali Kronika poletne šole klasičnih jezikov v Arkadiji
}

I

V zgodnjih jutranjih urah 23. junija 2018 se je začelo potovanje v Grčijo. Tako smo se, kot nekoč lord Byron, podali v deželo, ki kot zibelka evropske kulture in misli še danes buri domišljijo ljudi. A preden se spustimo v pripoved o deželi Homerjevih junakov, naj povemo, da nas je pot tokrat vodila tudi skozi deželo »kjer mili 'si' nam na uho prihaja, « kot pravi Dante v Božanski komediji.

Italijansko podeželje je gotovo eden izmed bolj slikovitih in očarljivih prizorov na svetu. Ravnine, okrašene s polji sončnic in žita in s sem ter tja posejanimi cipresami, vzpenjajočimi se visoko v nebo, kot vrhovi zvonikov gotskih katedral, ki kažejo proti nebesnemu svodu, v daljavi pa se vzpenjajo megleni obrisi hribovite notranjosti dežele. Tudi italijanske vasice so v sozvočju s to podobo, a pogosto je njihov pristen ruralni videz prekinjen s silhueto tovarne ali sem in tja novejše stanovanjske zgradbe. To romanje po italijanskem podeželju se je končalo s prihodom v Ancono, ki je bil začetek pomorskega dela našega popotovanja.

Ko je v poznih večernih urah trajekt izplul iz pristanišča, smo s palube zrli na anconske hribe, ki so s svojimi stolpi počasi bledeli v modrini neba, ožarjeni z žarki večernega sonca.

Ob spremljavi bučečih valov in oglašanja galebov smo se podali proti odprtemu morju in opazovali, kako sonce veličastno tone za obzorje.

"Zdaj se bo, tako so verjeli stari Egipčani, bog Hor spustil v podzemlje, kjer se bo celo noč bojeval s silami zla in se naslednjega dne ponovno prikazal, če bo v boju zmagovit, « je rekel eden izmed mojih prijateljev. In tako so nas zaposlile misli na preteklost, ko je svet vedel manj, a bil v določenem smislu bogatejši; bil je poln čudežnih bitij in neverjetnih dogodkov, bil je čas, ko je že nekaj danes tako preprostega, kot je pojav dneva in noči, s tako silo burilo 
domišljijo ljudi, da je sprožilo nastanek neštetih zgodb, ki so bile vir navdiha še stoletja kasneje. Mar ni ravno $\mathrm{v}$ tem zapuščina antičnega sveta, od katerega so ostale le ruševine, ki kot Ozymandiasov kip sredi puščave v sonetu Percyja B. Shelleyja pričajo o njegovi nekdanji veličini?

II

Preostanek plovbe je potekal mirno in razen omembe težav s klimo, na katere smo naleteli ob prihodu v kabino in jih na srečo tudi s precejšnjo hitrostjo odpravili, ne potrebuje daljšega komentarja. Ko smo se približali Grčiji, je morje dobilo odtenek globoko temne modre barve, skozi ladijske line pa smo kmalu uzrli obalo dežele albanskih očetov in zatem že prve grške otoke.

Kmalu smo, kot je bila nekoč navada grških pomorščakov, pluli le še vzdolž obale, ki se je skoraj neopazno stapljala z modrino neba, po katerem so lenobno plavali sijoče beli puhasti oblaki. $V$ naše misli se je počasi prikradel tisti pustolovski duh, ki je razvnemal domišljijo prenekaterega popotnika, ko je ta od daleč razločil podobo Grčije, poln pričakovanj, ki so se hranila na neumrljivi sliki veličine antike.

Po pristanku v Patrasu smo se ponovno znašli na poti, ki nas je vodila skozi barvito grško pokrajino. Po vožnji med neskončnim številom oleandrov, ki rastejo ob cestah in krasijo podobo pokrajine s svojimi vijoličnimi in belimi cvetovi, je dežela počasi dobila bolj gorate odtenke. Podoba mest se je prevesila v slike podeželskih vasi, ki so se druga za drugo izgubljale v daljavi.

$\mathrm{V}$ mnogih izmed grških vasi je moč opaziti kip, posvečen lokalnemu junaku, ki se je s pogumom in drznostjo izkazal v času grške osamosvojitve in si prislužil mesto na straneh zgodovine svojega naroda; hiše so preproste in povečini niso v celoti zgrajene, na mnogih dvoriščih s pogledom na cesto pa lahko opazite slikovito podobo starega Grka, ki s palico v roki brezskrbno sedi na svojem stolu in s pogledom spremlja popotnike, ki jih je zaneslo v te odročne kraje.

Sonce je že začelo zahajati in noč je počasi razprostrla svoj plašč čez nebo, na katerem so se kmalu začele prižigati prve zvezde. Po dolgi in izčrpni poti smo naposled zagledali podobo hotela, ki se je, osvetljena z mehko svetlobo luči, ločila od v temo ovitega obzorja.

III

Kraj našega kratkega bivanja, očarljiva vasica z imenom Vitina, ki ima vse odlike grške podeželske naselbine, leži v samem središču Peloponeza, Arkadiji.

Pokrajina je v tem predelu Grčije gorata, nebo je sivo in oblačno, povsod okrog pa se razprostirajo gozdovi košatih smrek, iz katerih se dvigujejo bele meglice. 
V nekoliko otožnem vzdušju deževnega dne smo prisluhnili predavanju gospoda Braneta Senegačnika na temo Oresteje, trilogije grškega dramatika Ajshila, ki so mu v prihodnjih dneh sledila še mnoga druga predavanja z zgodovinsko oziroma filozofsko tematiko; med njimi je bilo tudi izredno zanimivo predavanje, naslovljeno Et in Arcadia ego, v katerem nam je gospod Boris Šinigoj preko antičnih opisov Arkadije, ki se je razvila v simbol za raj, in baročnih upodobitev, ki so prevzela omenjeno simboliko, predstavil motiv et in Arcadia ego, stavka, ki ga izreka smrt in s tem potrjuje svojo prisotnost tudi v raju.

Sledilo je delo v skupinah, ki so bile tematsko razdeljene, v eni izmed njih, zgodovinsko-dramski, ki jo je vodila Andreja Inkret, je bilo, na primer, govora o interpretaciji lika Elektre; kmalu zatem pa smo se napotili proti ruševinam Miken.

Vreme se je postopoma izboljševalo in kmalu se je pred nami odprla podoba slikovitega in razgibanega reliefa, ki se razprostira okoli Miken in je pokrit $\mathrm{z}$ rumeno suho travo, sem in tja pa je presekana $\mathrm{z}$ gručo visokih dreves ali s čudovitimi grmi oleandrov, ki se bohotijo visoko nad glavami mimoidočih. Mogočne ruševine Miken se kljubovalno dvigujejo nad pokrajino, čeprav stojijo na vrhu najnižje izmed skupine treh vzpetin. V neposredni bližini se nahaja tudi kupolasta grobnica, v katero so pokopavali vladarje, danes pa je prazna, skrita pred pogledi med krošnjami dreves.

Do utrdbe vodi lepo urejena pot, ki se v okrilju borovcev vzpenja proti vhodu, nad katerega je spretnost antičnih umetnikov vklesala podobi dveh levov, ki pričata o že davno ugasli veličini mikenskih kraljev.

A veličastno obzidje, ki so ga, kot pravi legenda, zgradili kiklopi, zdaj brani le mestne temelje, ki se kot poslednji spomin iz davnine upirajo zobu časa. Kjer so nekoč stala utrjena bivališča in kamnita palača, se zdaj le še tu in tam nad ruševinami sklanja samotno drevo.

Ob povratku v Vitino smo se ustavili v manjši krčmi, v kateri nas je pričakala večerja. Za omizjem, kjer sem sedel s prijatelji, se je vnela živahna debata o grški kulinariki, katere prve vzorce smo prejeli v obliki grške solate, grške fete, prelite z olivnim oljem, in omake iz bučk in jogurta, ki nosi zanimivo ime tzatziki ter je, kot so me podučili, zapuščina Osmanskega cesarstva na grških tleh.

Zadovoljni s prvo gurmansko izkušnjo smo pričakovali glavne jedi, ki je že vztrajno prihajala na sosednje mize. A naše strahove, da bi bili prikrajšani za večerjo, je kmalu pomiril presenečen pogled natakarja, zgroženega nad dejstvom, da smo ostali pozabljeni, ki je takoj pred nas postavil krožnik poln grške ustreznice ražnjičev, imenovane suvlaki.

Od tistega trenutka je bilo naše omizje deležno neizmerno ustrežljive pozornosti. Takoj sta se pred nami pojavila dva vrča polna vode in v trenutku, ko je gladina v enem izmed njiju padla za centimeter ali dva, še dodatni vrč, ki je 
zagotovil, da bodo naši kozarci vedno polni. Pred vsakim se je kmalu znašel še krožnik nabito poln z novo porcijo suvlakijev in prilogo ocvrtega krompirja, nato pa so nas vztrajno zalagali z dopolnilnimi krožniki vsakič, ko so prejšnji začeli dajati vtis praznosti.

Ko se je obed že prevešal h koncu in je na vas legla trda tema, pa so mize nenadoma izginile, zazvenela je glasba in kot bi mignil, so vsi začeli plesati različne grške plese, ki se praviloma tako ali drugače plešejo v krogu.

Obogateni s to čudovito izkušnjo smo se v hotel vrnili mnogo pozneje, kot je bilo načrtovano, a se za to niti nismo zmenili.

Med znamenitostmi, ki smo jih imeli čast obiskati, je seveda tudi grška prestolnica.

Ko smo prispeli v območje Aten, se je pred nami izrisal zanimiv prizor. Na eni strani smo lahko občudovali klasično arhitekturo, ki je s svojo belino in skladnostjo $\mathrm{v}$ naših mislih prebudila prenekatero mitološko podobo antičnega mesta. A ko nam je pogled zdrsel z Akropole in smo se ozrli po obdajajočem mestu, se je sleherni privid veličine tega starodavnega kraja, ki se je še trenutek prej zdel tako resničen, razgubil v ostrih podobah resničnosti.

Kjer so nekoč stali visoki stebri, so zdaj le še razvaline. Ulice Aten so sicer lepo urejene, a v trenutku, ko zaviješ z glavne ceste in se sprehodiš po predelih mesta, kjer se ne gnetejo gruče turistov, se pred teboj razprostre podoba zanemarjenega, ugaslega mesta.

Ob vznožju Akropole smo se napotili proti Areopagu, manjšemu skalnatemu griču, ki je popolnoma gol in leži v neposredni bližini svoje večje geološke sorodnice.

Navkljub svoji neznatnosti v primerjavi z največjo atensko znamenitostjo ni nič manj bogat spomenik grške zgodovine.

Njegovo ime ima izvor v poimenovanju 'A $\rho \varepsilon ı \varsigma$ Пájoৎ ali Aresov grič in je prvotno služil kot sedež vrhovnega sodišča. Kasneje je postal neke vrste naravni govorniški oder, s katerega je lahko izobraženi del prebivalstva nagovoril vsakdo, ki je presodil, da so njegove ideje vredne delitve. V spomin Atencev se je zapisal predvsem zaradi te svoje zadnje funkcije, saj je z njega apostol Pavel nagovoril prebivalce mesta, kar še danes obeležuje kamnita plošča ob njegovem vznožju, na kateri so zapisane Pavlove besede.

Pot nas je kmalu popeljala do muzeja tradicionalnih grških glasbil, kjer hranijo lepe primerke buzukijev in raznovrstnih drugih brenkal, med katerimi se bodo bralcu verjetno zdele najzanimivejše grške mandoline. Te so razvile troje različnih oblik, ki imajo svoj izvor v različnih delih Grčije. Kretska je dobila ime kritiki, črnomorska pontiki in bizantinska politiki.

Etimologija zadnje je morda nekoliko nejasna. 
Grki, ki štejejo mesto Bizanc oziroma Istanbul, kakršno je njegovo ime danes, za svojo duhovno-zgodovinsko prestolnico, so mnenja, da je to edino mesto, ki si zasluži biti imenovano zgolj Mesto oziroma Пó $\eta$. Tako so glasbilo, ki prihaja iz Mesta, poimenovali po njem samem. Kmalu zatem smo se znašli na sprehodu po čudovitem parku, kjer se je nekoč nahajala grška Agora. Vijugasta pot, ki vodi mimo stoe in se vije med ruševinami, ki skupaj z nizkimi drevesi, rastočimi med njimi, ustvarijo sliko idilične podobe antične arhitekturne umetnosti, v kateri se zrcali skladnost narave, se je odpirala pred nami, obsijana s popoldanskim soncem in nas kmalu pripeljala na vrh manjše vzpetine. Tam smo se za kratek čas lahko ustavili v senci grškega templja, stoječega med visokimi cipresami.

A ker bralca dolgovezni opisi ruševin $\mathrm{z}$ opisovanjem čarov, ki jih pri tovrstnih krajih občudujejo obiskovalci že vse od časov, ko so se v njih ustavljali mladi popotniki potujoči po deželah tako imenovanega Grand Toura, ne bodo preveč zanimali, se bomo na tej točki ustavili, preskočili nekaj poglavij naše pripovedi, ki vključujejo nič več kot skromno kosilo in kratek sprehod po ulicah znamenitega atenskega bolšjega sejma, in našo pripoved nadaljevali pred vrati atenske stolnice.

Katedrala, ki je sedež grškega patriarha, je v svojem unikatnem slogu nedvomno biser mesta. Bizantinska sakralna arhitektura se na njeni zunanjosti prepleta $\mathrm{z}$ rimskokatoliško tradicijo, kar je moč zaznati v obliki njenega pročelja in zasnove v obliki latinskega križa.

Notranjost je presunljiva. S stropa, obarvanega v zamolklo modro barvo, na katerem je upodobljeno zvezdnato nebo, visijo veličastni zlati lestenci, stene so umetelno poslikane s prepletajočimi se vzorci, na visokem zidu, ki ločuje oltarni del od preostanka cerkve, pa visijo čudovite ikone $\mathrm{z}$ upodobitvami svetnikov. Ko s pogledom sledite tem podobam, se vam oči kmalu ustavijo na kupoli, katere obod krasijo angeli, z njene notranjosti pa navzdol zre strogi Odrešenikov obraz.

Posebnost grške pravoslavne cerkve je, da je v načinu svojega delovanja in razmišljanja ohranila skoraj vse navade iz časov bizantinskih cesarjev. Še vedno v Kristusovi podobi išče zgled nebeškega kralja, ki kot pravičen vladar in sodnik zre na Zemljo s svojega prestola, o čemer jasno priča vse razkošje, s katerim so graditelji opremili stolnico.

Že samo vzdušje v katedrali vzbuja občutek skrivnostnosti in zelo jasno je, da s tem, ko prestopiš veličastne duri, vstopaš v posvečen prostor. Ta je le šibko osvetljen s svetlobo sveč in sonca, ki se občasno prebije v notranjost skozi majhne okrogle vitraje, a ko skoznje posvetijo žarki dnevne luči, se pisanih barv razpršijo po prostoru in odbijajo od zlatih ornamentov in dragih kamnov, ki za trenutek začnejo žareti, kot tisoče majhnih plamenov.

Prav zato pride okrasje cerkve do večjega izraza, kot bi se dogajalo v primeru, ko bi bila osvetljava enaka kot v prenekateri drugi znameniti evropski katedrali. Na cerkev moramo zreti kot na celostno umetnino, ki se nam kot taka pokaže le tedaj, ko so ustvarjeni pogoji, kakršne si je zamislil njen 
arhitekt. Šele takrat začne presegati zgolj svojo fizično podobo in pridobi tudi miselno, duhovno komponento, ki je ne le sporočilna, temveč ustvarja tudi pogoje, pod katerimi je potrebno sporočilo sprejeti, da bo lahko zažarelo $\mathrm{v}$ polnosti svojega pomena.

Prevzeta od čarobnega prizora sva se s prijateljem podala do poslednjega kraja, ki sva se ga pred iztekom dne odločila obiskati - narodnih vrtov. Zasaditi jih je po angleškem zgledu ukazala grška kraljica Amalija, žena kralja Otona, a ker za turiste niso preveč privlačna atrakcija, so danes močno zanemarjeni.

Počasi sva se sprehodila med eksotičnimi drevesi, ki so kljub vsemu še izžarevala nekaj isker življenja, in prispela do kraja, kjer v znak večne zahvale grškega ljudstva stoji spomenik Lordu Byronu. Na njem je upodobljen pesnik, nad katerim poosebitev Grčije s hvaležnostjo drži palmov list, simbol večnosti, na posvetilni plošči pa so zapisane naslednje besede:

\author{
$\mathrm{H} \mathrm{E} \Lambda \Lambda \mathrm{A} \Sigma$ \\ TON BYP $\Omega N A$ \\ Grčija (počasti) Byrona.
}

Lord Byron je v svojem življenju večkrat potoval $\mathrm{v}$ dežele večnega poletja, kot jih je sam opisal v eni svojih pesmi, tu pa je leta $1824 \mathrm{v}$ mestu Mesolongi tudi umrl. Prispel je v želji, da bi pomagal grškemu ljudstvu osvoboditi se izpod jarma Osmanskega cesarstva in si tako prislužil mesto narodnega junaka $\mathrm{v}$ spominu prebivalcev Grčije.

Tako se je končal obisk Aten in pesnikov samotni kip, ki nekoliko pozabljen in neopažen še vedno stoji med cvetočimi rožami in sanja o času, ko sonce antike še ni izginilo za obzorjem, je počasi zbledel v daljavi.

The isles of Greece! The isles of Greece

Where burning Sappho loved and sung,

Where grew the arts of war and peace,

Where Delos rose, and Phoebus sprung!

Eternal summer gilds them yet,

But all, except their sun, is set.

\title{
/.../
}

Must we but weep o'er days more blest?

Must we but blush? - Our fathers bled.

Earth! Render back from out thy breast

A remnant of our Spartan dead!

Of the three hundred grant but three,

To make a new Thermopylae! (Lord G. G. Byron, »The Isles of Greece«) 
Če smo poprej imeli čast spoštovanega bralca popeljati po pokrajinah celinske Grčije in mu na kratko in, kot upamo, čim bolj zvesto orisati njihove poteze, nam bo sedaj v veliko veselje nekaj malega povedati še o grških obalnih mestih, ki so ravno tako očarljiva kot njihovi sorodniki v notranjosti države.

$\mathrm{Na}$ jugovzhodu peloponeškega polotoka se nahaja čudovito pristaniško mesto Navplio, ki je na straneh zgodovine večkrat zapisano na pomembnejših mestih, najbolj znano pa je po svoji vlogi v času Prve grške republike, ko je postalo prestolnica novonastale države.

Nad mestom se ob obali dviguje dvoje svojevrstnih klifov, na katerih stojita trdnjavi, postavljeni še v času, ko je bilo mesto del Beneške republike. O tem priča simbol ponosnega beneškega leva, vklesan $\mathrm{v}$ steno ene izmed trdnjav.

Klifa zreta na prelep zaliv. V njem se v soju sonca penijo lesketajoči valovi, ki se nato $\mathrm{z}$ bobnečim glasom lomijo na skalah dvigajoče se stene.

V senci nižje ležeče od trdnjav je ob obali idilična kamnita pot, ki se vije med dvigajočo steno, po kateri rastejo veliki cvetoči kaktusi, in košatimi borovci, ki s svojimi krošnjami blago valovijo v vetru.

Pljuskajoče morje, popoldansko sonce, ki s toplimi žarki sije na zaliv, rezko oglašanje škržatov, ki se skrivajo v krošnjah očarljivih borovcev in prelepa pot, ki zavije za steno klifa in se skrije pred pogledom sprehajalca le zato, da mu lahko v naslednjem trenutku odpre pogled na nov osupljiv prizor! Tako smo se v prijetnem razpoloženju mimo trdnjave podali po obmorski stezi, ki je počasi vijugala skozi ob njej rastoče kaktuse in nam, potem ko je zavila skozi naravni tunel $\mathrm{v}$ steni klifa, odstrla pogled na drugi del zaliva, ob katerem stoji mesto.

Postopoma se je pot začela spuščati proti mestu in kmalu smo se znašli ob bronastih beneških topovih, ki še vedno stojijo na ostankih mestnega zidu. Nedaleč od pristanišča na majhnem otoku stoji kamnita trdnjava, ki močno spominja na znamenito Trdnjavo If ob obali Marseilla, ki je poznana predvsem po svoji vlogi v romanu francoskega pisatelja Alexandra Dumasa Grof Monte Cristo in je od časov kralja Françoisa I., ki jo je dal zgraditi, služila kot zapor za najhujše politične zapornike. Le kakšna je zgodovina utrdbe, ki je stala med valovi le streljaj od obale in naših pogledov?

Pot smo nadaljevali, očarani nad vzdušjem, ki je prežemalo mesto in njegovo okolico, ter se podali po njegovih ulicah. Kmalu smo odkrili, da je italijanski duh beneške republike v mestu še vedno prisoten, o čemer so nas prepričale številne "gelaterie«, pa tudi dve rdeči zastavi z izvezeno podobo beneškega leva na stavbi, ki je dajala vtis mestne hiše, na glavnem trgu mesta.

Vendar je prisotnih tudi nekaj spomenikov, ki vseeno dokazujejo, da gre za grško mesto. Kot smo že omenili, je bilo to prestolnica Prve grške republike. Predsednik te republike je bil Joannis Kapodistrias, katerega predniki so bili najverjetneje plemiči iz Slovencem dobro znanega mesta Koper, po njem pa 
je rodbina dobila tudi ime. Zgodba njegovega življenja je pestra, zaključi pa se leta 1831, ko je bil nanj izveden atentat, to pa je pripeljalo tudi do propada Prve grške republike in do ustanovitve Kraljevine Grčije, na katere prestol je sedel mladi bavarski knez Oton I.

Danes Kapodistrias velja za enega izmed najspretnejših politikov v grški zgodovini, v počastitev njegovega spomina pa v središču mesta stoji njegov kip.

Mesto si zasluži tudi kulinarično pohvalo, saj se je tamkajšnji sladoled, ki je očitno zapuščina Italijanov, izkazal za izjemno osvežilnega in bogatega z okusom, pohvaliti pa gre seveda tudi odličen grški giros, okusno jed, ki vsebuje meso, čebulo, več omak, paradižnik in ocvrti krompirček, vse skupaj pa je ovito v popečen kruh. Ko se je sonce že začelo spuščati proti morju in je nebo počasi obarvalo $\mathrm{v}$ oranžno, smo ob obali našli klop v senci dveh košatih palm in se zazrli na nasprotno stran zaliva, kjer so po valovečem morju počasi drsele bele jadrnice.

Je mar na svetu moč najti prizor, bolj navdihujoč in zaznamovan s simboličnim pomenom od jadrnice, ki v svetlobi gorečega večernega sonca pluje proti obzorju? Jadrnica - simbol človeka, ki pluje po morju, vedno znova iščoč južni otok iz pesmi Kajetana Koviča, v nekem daljnem neznanem morju ... Nad njim se sončna luč razžarja, / pod njim je morje v dalj in šir. / A jadro si želi viharja, / kot da v viharju bil bi mir! ${ }^{1}$

VI

Med dogodki, ki smo jih doživeli med našim bivanjem v Grčiji, naj na kratko omenimo še dva, ki sta lepo popestrila tudi nekaj večerov. Prvi med njimi je glasbeni večer, ki je imel sicer skromno udeležbo, a je izkušnja v mislih tistih, ki so bili prisotni, gotovo pustila trajen in prijeten spomin.

Ko smo se zbrali na udobnih usnjenih naslanjačih v nekoliko odmaknjenem predelu hotelskih skupnih prostorov in ob razmišljanju o izvoru in zgodovini rembetiko glasbe, o kateri nas je poučil gospod Šinigoj in se je v Grčiji razvila v času Osmanskega cesarstva, prisluhnili njenim otožnim melodijam, se je pred nami razkril del grške kulture, popolnoma drugačen od tistega, ki ga vidimo skozi oči stoletij, zaverovanih v ideal antike. V slednjega, kot se zdi, Grki sami še vedno verjamejo, čeprav bi v resnici sami ne mogli biti bolj oddaljeni od njega. Drugi tak večer je bil literarni večer, na katerem smo lahko prisluhnili poeziji gospoda Senegačnika ob glasbeni spremljavi gospoda Šinigoja, ki je tudi tokrat na raznovrstne različice buzukijev postregel z melodijami rembetika, sledilo pa je nekaj nastopov, med katerimi je bila tudi humorna priredba Zenonovega paradoksa o Ahilu in želvi. Ta je že stoletja predmet mnogih razprav in dokazovanj, čeprav njegova razrešitev sploh ni bila Zenonov namen.

1 Mihail J. Lermontov, Jadro 9-12 
Gre za tekmovanje v teku med želvo in Ahilom. Ahil, ki je seveda najurnejši tekač, počasni želvi odstopi nekaj prednosti. Tekma se začne, Ahil hitro preteče razdaljo, ki jo je pretekla želva, a želva je še vedno pred njim, saj je v času, ki ga je porabil za to, da je prispel na mesto, kjer je želva bila, ta spet pretekla neko, sicer manjšo razdaljo. Tako se to lovljenje nadaljuje v neskončnost in čeprav Ahilu vedno znova uspe zmanjšati razdaljo, mu želve nikoli ne uspe ujeti.

Namen te in podobnih Zenonovih domislic ni bil takšno ali drugačno dokazovanje naravnih zakonitosti. S tem je, podobno kot so to budistični menihi počeli s problemi, imenovanimi zen-koani, hotel le opozoriti na dejstvo, da lahko z določenim načinom razmišljanja kot paradoks predstavimo marsikatero očitno dogajanje. S tem pa je odgovoril na nasprotovanja nekaterih drugih filozofov, ki se niso strinjali z njegovimi nazori.

\section{VII}

29. junija smo se napotili proti Olimpiji, ki je bila zadnja postojanka našega popotovanja. Ostanki mnogih templjev in samega stadiona so zanimivi pričevalci o zgodovini grškega športa in nam pogosto pokažejo, da za Grke šport ni bil le tekmovanje v premagovanju nasprotnika na ravni njegovega telesa, ampak predvsem izpopolnjevanje $\mathrm{v}$ harmoniji med mislijo in fizično zmogljivostjo. Šport je tako skozi stoletja prehodil dolgo pot in se na njej močno oddaljil od svojega prvotnega namena. Počasi se je spremenil v nekaj, kar še najbolje zaznamuje geslo panem et circenses, a vsakemu posamezniku prepuščamo, da do slednjega zavzame svoje lastno stališče.

S tem smo našo pripoved pripeljali do njenega zadnjega prizora. Bralcu se iskreno zahvaljujemo za njegovo potrpežljivost in upamo, da se mu je zdela zanimiva in poučna.

29. junija smo v poznih popoldanskih urah ob spremstvu galebov zapluli v Jadransko morje in kmalu so grške dežele za nami zbledele v daljavi ... 


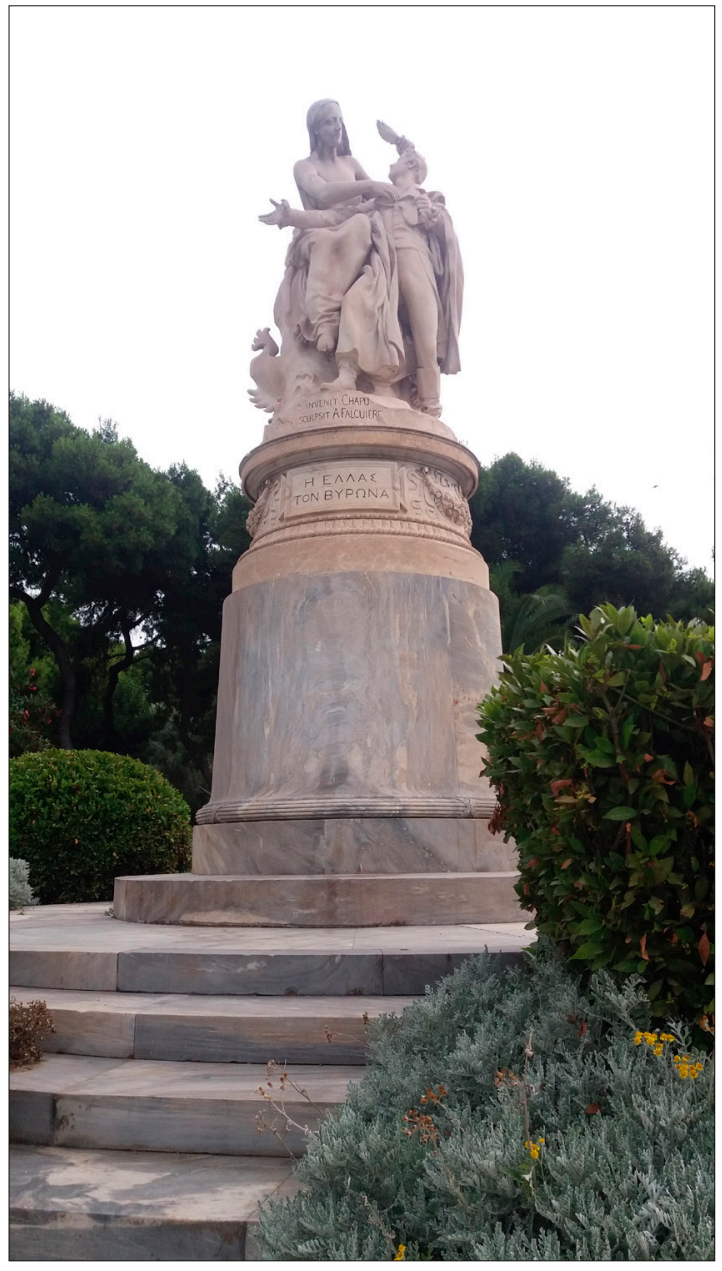

Slika: Byronov spomenikv Atenah 